\title{
Studies of the Reproductive Biology of Toona ciliata M. Roem under the Himachal Pradesh Condition
}

\author{
Thiyam Jefferson Singh* and Tara Gupta
}

\begin{abstract}
Dept. of Tree Improvement and Genetic Resources, Dr. Yashwant Singh Parmar University of Horticulture \& Forestry, Nauni,
\end{abstract} Solan, H.P. (173 230), India

\section{Corresponding Author}

Thiyam Jefferson Singh

e-mail: lampardleo@gmail.com

\author{
Article History \\ Manuscript No. AR1737 \\ Received in $20^{\text {th }}$ November, 2016 \\ Received in revised form $29^{\text {th }}$ April, 2017 \\ Accepted in final form $5^{\text {th }}$ June, 2017
}

\begin{abstract}
Toona ciliata is an important timber species of India which is found in H.P. as natural populations, mostly along the cultivated fields and roads. The present studies on various facets of reproductive biology were conducted under the Dept. of Tree Improvement and Genetic Resources during 2011 in which three sites namely Jaunaji, Dharja and Kandaghat with elevations $1400 \mathrm{~m}, 1215 \mathrm{~m}$ and $1180 \mathrm{~m}$ respectively in district Solan. The studies included full coverage of phenophases as a physiological basis of reproductive growth. The phenological studies included the morphological characters such as leafing, flowering and fruiting in which leaf bud appearance was first observed in $L_{2}(D h a r j a)$ followed by $L_{1}$ (Jaunaji) and $L_{3}$ (Kandaghat). Fruit development at first instance was recorded in $L_{1}$ (Jaunaji), $L_{2}$ (Dharja) and the lastly from $\mathrm{L}_{3}$ (Kandaghat). The floral morphology was also one of the parameter in which the type of inflorescence was observed to be consisting of numerous flowers born in thyrse bearing paniculate racemes at the apex of the branchlets bearing compound leaves. The flowers are functionally unisexual but morphologically bisexual. Calyx is polysepalous. Corolla was found to have five equal sized petals which were longer than the calyx and adnate near the base. Anthesis of flowers was observed to take place between 7.00 a.m. to 1.00 p.m. for all the three localities. The mode of pollination was observed to be both cross and self pollination but tends to be out crossed.The pollen grains exhibited a light creamish colour. Pollinators were found to be thrips and bees.
\end{abstract}

Keywords: Reproductive biology, phenological studies, Toona ciliata

\section{Introduction}

Toona ciliata belonging to family Meliaceae, is the best known Indian timber species, popularly known as toon and red cedar. The other timber yielding species of the genus occurring in India are Toona febrifuga, T. microcopa and T. serrata. Meliaceae is in fact the backbone of forest industries in many countries (Bahadur, 1988). In India it is found throughout the Sub-Himalayan tract and the valleys of the outer Himalayas, plains of Assam, Madhya Pradesh, Tamil Nadu, Karnataka, Eastern and Western Ghats occurring up to an elevation of $1200 \mathrm{~m}$ (rarely $1300 \mathrm{~m}$ ) in western peninsula Khasihills and Manipur (Singh, 1982). It is a characteristic tree of Eastern alluvial secondary semi-evergreen forests in Assam (Champion and Seth, 1968), ecologically tree is restricted to the site where the absolute shade temperature varied from $37.5-47.5^{\circ} \mathrm{C}$ and the absolute mean from $-1-17.5^{\circ} \mathrm{C}$, the annual rainfall ranges from $1100-4000 \mathrm{~mm}$. Most of the plants bearing biological activity one such species is Toona ciliata (Meliaceae) which has been exploited for many traditional uses like construction purpose, dye preparation, furniture, medicines etc., (Negi et al., 2011). Toona ciliata along with
Siderin, a compound isolated from petroleum ether extract showed significant antibacterial activity and also exhibited significant cytotoxicity (Chowdhury et al., 2003). The plant extract also showed gastro protective activity (Malairajan et al., 2006). The inhibitive effects on formed protein nonenzymatic glycation an end product was studied from the ethanolic leaf extract (Shao-Hong, 2010) Cedrelone, a tetra nortriterpenoid, isolated from Toona ciliata (Gopalakrishnan et al., 2000). Success of tree improvement generally depends upon the combination and expression of characters in the new genotypes which holds the key for boosting the productivity and yield of the economic product. In this context, regulation of variation through reproductive system forms the basic approach which is dependent upon the information pertaining to reproductive biology as the biological process. Therefore, the studies on reproductive biology and breeding system are pre-requisite for developing appropriate strategies for tree breeding. There is a felt need to take up the detailed study of Toona ciliata- a multipurpose, timber species, particularly because of its typical inflorescence showing indeterminate growth pattern. 


\section{Materials and Methods}

The present investigation entitled "Reproductive biology of Toona ciliata M. Roem" was carried out in the Department of Tree Improvement and Genetic Resources, Dr. Y.S. Parmar University of Horticulture and Forestry, Nauni-Solan (H.P) during 2009-2011 Three locations were randomly selected for study of phonological such as leafing, flowering, fruitingand morphological studies such as floral morphology, floral biology and breeding system of Toona ciliata. The locations selected were Jaunaji $\left(L_{1}\right)$, Dharja $\left(L_{2}\right)$ and Kandaghat $\left(L_{3}\right)$ and from each locations 9 medium sized trees were selected.On each tree 5 branches were tagged/marked with metallic tags and numbered from 1-5. Further it is important to mention here that the selected trees were not lopped in the previous year as well as during the study period.

These studies were conducted on the three selected sites represented by 9 trees from each location in district Solan, H.P. Table 1(a) and Figure 1. Five branches and five inflorescences were marked with tags for studying the following phenophases and floral characteristics.

Table 1(a): Three selected study sites for phenological, morphological and breeding system of Toona ciliata

\begin{tabular}{lcccc}
\hline Locations & Altitude & Latitude & Longitude & Code \\
Jaunaji & 1400 & $30^{\circ} 54^{\prime} \mathrm{N}$ & $77^{\circ} 06^{\prime} \mathrm{E}$ & $\mathrm{L}_{1}$ \\
Dharja & 1215 & $30^{\circ} 51^{\prime} \mathrm{N}$ & $77^{\circ} 10^{\prime} \mathrm{E}$ & $\mathrm{L}_{2}$ \\
Kandaghat & 1180 & $30^{\circ} 59^{\prime} \mathrm{N}$ & $77^{\circ} 07^{\prime} \mathrm{E}$ & $\mathrm{L}_{3}$ \\
\hline
\end{tabular}

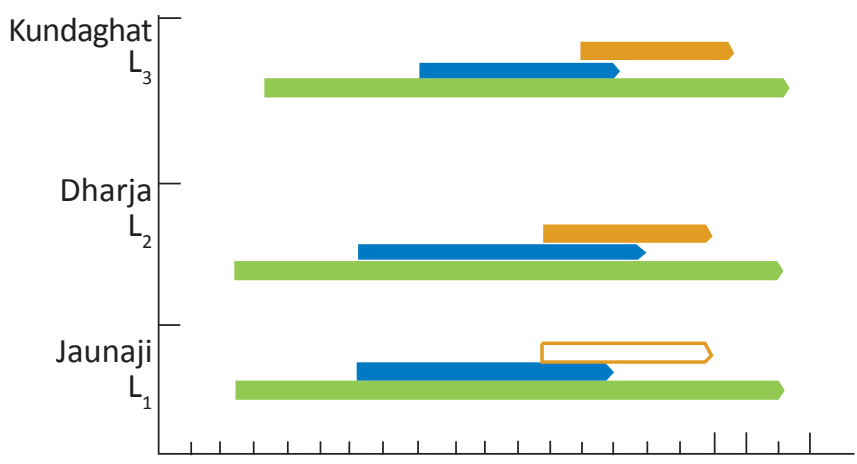

$W^{1} W^{2} W^{3} W^{4} W^{1} W^{2} W^{3} W^{4} W^{1} W^{2} W^{3} W^{4} W^{1} W^{2} W^{3} W^{4} W^{1} W^{2} W^{3} W^{4}$ February March April May June Index:- Leafing : Flowering: $\quad$ Fruiting: $W^{1}: 1^{\text {st }}$ week; $W^{2}: 2^{\text {nd }}$ week; $W^{3}:{ }^{3 r d}$ week; $W^{4}: 4^{\text {th }}$ week

Figure 1: Phenogram showing phenophases of Toona ciliata during February 2011 to June 2011

\subsection{Phenological studies}

The selected sites were frequently visited after marking the branches in the selected trees. The morphological changes, in the shape and size of leaf buds during the development were recorded from the time of emergence to the full leafing stage. Leaflet number of five leaves from different shoots per selected tree was recorded in centimeters $(\mathrm{cm})$ when fully grown. The morphological changes, in the shape and size of flower buds during their development have been observed from the time of their emergence to the anthesis stage and different stages of bud development under lab condition. Five stages were identified for bud development and flowering. The time and duration of fruit set were observed by visiting individual trees of the selected sites and further five inflorescences per tree were observed and date of first and last fruit were recorded.

\subsection{Floral morphology and breeding system}

Different parts of the flower have been examined and their size, colour, and system of arrangement studied carefully. Number of stamens per flower on the basis of ten observations in nine trees was recorded. Inflorescence type was determined on the basis of the arrangement of flowers on the stem and grouped according to the classification given by Weberling (1989). Both the qualitative and quantitative characters of the flower were studied at full bloom stage. The mode and manner of flower opening were observed from the moment petals begin to open till the flower fully opens. Early morning onwards, numbers of fully opened flowers were noted at an hour interval. The bud stages were compared for their appearance, size, texture and compactness, in order to decide the stages. Prior to anthesis, the mode of anther dehiscence were carefully observed and recorded for each flower tagged, in this way ten flowers were observed individually to determine the time of anther dehiscence in each flower. Buds at all the identified stages were physically examined under dissection microscope for anther dehiscence and adherence of pollen to anther surface. The stages at which such adherence of pollen was observed, was taken as the anther dehiscence stage. Stigmatic surface of all the stages was carefully observed under microscope and features recorded. The stage where pollen germination on stigmatic surface was observed was taken as the stigma receptive stage.

To determine the breeding system matured flower buds were taken from the inflorescence on watch glass and gently tapped for pollen and pollination study. Also flower buds expected to open next day were collected, anthers removed and kept on a piece of butter paper under partial shade for dehiscence. Pollen grains thus collected were put in glass vials and kept at room temperature $\left(25^{\circ} \mathrm{C}\right)$. To study the pollen morphology the occular micrometer were standardized with stage micrometer. Pollen grains were dusted on the slides uniformly with the help of aceto carmine stain (1\%) and covered with a cover slip. The measurement of pollen grain was recorded with ocular micrometer. The activities of flower visitors/pollinators were carefully observed throughout the flowering period on the trees, inflorescences collected in paper bags, the pollen vectors collected and identified. For studying the self-incompatibility, five inflorescences per tree on all the nine trees from each locations were allowed to self-pollinate by putting a pollination bag on initial stages of floral bud development. 


\section{Results and Discussion}

\subsection{Phenological studies}

The phenophases in all the three sites under study exhibited variable leaf flushing time vis-a-vis floral development periods which can be attributed to more of the prevailing environmental variables and locality factors responsible for wood characteristics and tree physiology. The studies can be supplemented by the findings of Heinreich and Banks (2006) where the time period between rejuvenation of growth and leafless period influenced the growth reaction in early wood and late wood (Table 1).

Regarding the leaf flushing, one week time interval was observed which was useful and could be utilized for dendro climatological investigations, at different sites. Apart from physiological basis of growth cessation and activation deciding leafless stage, the response of individual trees for prevailing climatic conditions was also noted however the results have

Table 1: Phenophases of Toona ciliata at different selected sites

\begin{tabular}{|c|c|c|c|c|c|}
\hline \multirow[t]{2}{*}{ Sites } & \multirow{2}{*}{$\begin{array}{l}{ }^{*} \text { Leaf bud ap- } \\
\text { pearance }\end{array}$} & \multirow[t]{2}{*}{ Leaf appearance } & \multicolumn{2}{|c|}{ Duration of flowering } & \multirow{2}{*}{$\begin{array}{c}\text { Duration of fruit } \\
\text { development }\end{array}$} \\
\hline & & & $\begin{array}{l}\text { Floral bud } \\
\text { initiation }\end{array}$ & $\begin{array}{l}\text { Floral bud and inflo- } \\
\text { rescence development }\end{array}$ & \\
\hline $\mathrm{L}_{1}$ & $\begin{array}{l}3^{\text {rd }} \text { week of } \\
\text { February }\end{array}$ & $\begin{array}{l}2^{\text {nd }} \text { week end of } \\
\text { March }\end{array}$ & $\begin{array}{l}3^{\text {rd }} \text { week of March to } 4^{\text {th }} \text { week } \\
\text { of March }\end{array}$ & $\begin{array}{l}2^{\text {nd }} \text { week of April to } 3^{\text {rd }} \\
\text { week of May }\end{array}$ & $\begin{array}{l}1^{\text {st }} \text { week of May- } \\
2^{\text {nd }} \text { week of June }\end{array}$ \\
\hline $\mathrm{L}_{2}$ & $\begin{array}{l}3^{\text {rd }} \text { week of } \\
\text { February }\end{array}$ & $\begin{array}{l}2^{\text {nd }} \text { week of } \\
\text { March }\end{array}$ & $\begin{array}{l}\text { End of } 3^{\text {rd }} \text { week of March to } \\
\text { end of } 4^{\text {th }} \text { week of March }\end{array}$ & $\begin{array}{l}2^{\text {nd }} \text { week of April to } 4^{\text {th }} \\
\text { week of May }\end{array}$ & $\begin{array}{l}1^{\text {st }} \text { week of May- } \\
2^{\text {nd }} \text { week of June }\end{array}$ \\
\hline $\mathrm{L}_{3}$ & $\begin{array}{l}4^{\text {th }} \text { week of } \\
\text { February }\end{array}$ & $\begin{array}{l}3^{\text {rd }} \text { week of } \\
\text { March }\end{array}$ & $\begin{array}{l}\text { First week of April to begin- } \\
\text { ning of } 2^{\text {nd }} \text { week of April }\end{array}$ & $\begin{array}{l}2^{\text {nd }} \text { week of April to } 3^{\text {rd }} \\
\text { week of May }\end{array}$ & $\begin{array}{l}2^{\text {nd }} \text { week of May- } \\
3^{\text {rd }} \text { week of June }\end{array}$ \\
\hline
\end{tabular}

been documented on locality/site basis showing time interval and days taken to complete the phenophase.

Non significant effect of leaflet size (Table 2) but significant result for trees within the sites indicates the individual tree variation for this parameter as a matter of inherent potentials. The number of leaflets was found to register significant

Table 2: Mean no. of leaflets and leaflet size in different sites

\begin{tabular}{lcccccc}
\hline $\begin{array}{l}\text { Tree- } \\
\text { No. }\end{array}$ & \multicolumn{3}{c}{ Mean no. of leaflets/leaf } & \multicolumn{3}{c}{$\begin{array}{c}\text { Mean leaflet } \\
\text { size }(\mathrm{cm})\end{array}$} \\
\cline { 2 - 7 } & $\mathrm{L}_{1}$ & $\mathrm{~L}_{2}$ & $\mathrm{~L}_{3}$ & $\mathrm{~L}_{1}$ & $\mathrm{~L}_{2}$ & $\mathrm{~L}_{3}$ \\
\hline $\mathrm{T}_{1}$ & 12.4 & 13.4 & 11.8 & 8.26 & 8.64 & 9.60 \\
$\mathrm{~T}_{2}$ & 13.8 & 13.8 & 13.2 & 7.20 & 9.60 & 8.84 \\
$\mathrm{~T}_{3}$ & 16.0 & 12.6 & 12.4 & 8.42 & 8.84 & 9.60 \\
$\mathrm{~T}_{4}$ & 13.0 & 12.6 & 14.0 & 8.64 & 9.60 & 7.20 \\
$\mathrm{~T}_{5}$ & 15.4 & 13.6 & 12.2 & 9.60 & 8.84 & 8.42 \\
$\mathrm{~T}_{6}$ & 13.6 & 14.2 & 12.8 & 8.84 & 6.70 & 8.64 \\
$\mathrm{~T}_{7}$ & 13.0 & 13.4 & 12.8 & 6.70 & 8.84 & 6.70 \\
$\mathrm{~T}_{8}$ & 16.0 & 16.2 & 16.4 & 9.62 & 6.70 & 8.84 \\
$\mathrm{~T}_{9}$ & 16.2 & 13.2 & 12.4 & 9.58 & 9.62 & 6.70 \\
Mean & 14.38 & 13.67 & 13.11 & 8.54 & 8.60 & 8.28 \\
\hline
\end{tabular}

variation for both the factors i.e. sites and tree within the site; therefore better number of leaflets per leaf can be taken as a selection criterion while improving lean period fodder tree species. The floral bud and inflorescence development of this species was focused to locate variation if any but no striking variation on flower morphology could be traced. However the flower bud size and corresponding floral parts were found to indicate the relative dimensions of floral parts enclosed within it; at different positions of the panicle (Table 3 ). This was assigned reason of morphological size differences observed between them owing to differential patterns of organ elongation and relative slow growth occurring proportionately in the floral parts at later stages of inflorescence growth when the panicle follows indeterminate growth pattern. The inflorescence growth was considered to be further influenced by the scarce and shared translocation of mineral nutrients. Similar findings are reported by Gouvea et al. (2008) while

Table 3: Mean inflorescence length and no. of flowers at different sites

\begin{tabular}{lcccccc}
\hline $\begin{array}{l}\text { Tree } \\
\text { no. }\end{array}$ & \multicolumn{3}{c}{$\begin{array}{c}\text { Mean inflorescence } \\
\text { length(cm) }\end{array}$} & \multicolumn{3}{c}{ Mean no. of flowers } \\
\cline { 2 - 7 } & $\mathrm{L}_{1}$ & $\mathrm{~L}_{2}$ & $\mathrm{~L}_{3}$ & $\mathrm{~L}_{1}$ & $\mathrm{~L}_{2}$ & $\mathrm{~L}_{3}$ \\
\hline $\mathrm{T}_{1}$ & 25.70 & 23.40 & 17.60 & 569.80 & 528.20 & 528.20 \\
$\mathrm{~T}_{2}$ & 18.20 & 23.00 & 23.00 & 442.20 & 507.00 & 507.00 \\
$\mathrm{~T}_{3}$ & 20.32 & 17.40 & 26.60 & 465.40 & 477.40 & 477.40 \\
$\mathrm{~T}_{4}$ & 18.94 & 21.00 & 22.20 & 444.00 & 506.60 & 506.60 \\
$\mathrm{~T}_{5}$ & 24.14 & 26.20 & 20.40 & 519.40 & 588.40 & 588.40 \\
$\mathrm{~T}_{6}$ & 24.32 & 24.40 & 20.40 & 528.00 & 531.60 & 531.60 \\
$\mathrm{~T}_{7}$ & 20.22 & 21.60 & 19.20 & 492.60 & 502.40 & 502.40 \\
$\mathrm{~T}_{8}$ & 21.24 & 16.40 & 21.20 & 504.40 & 404.20 & 404.20 \\
$\mathrm{~T}_{9}$ & 21.86 & 22.00 & 20.00. & 511.80 & 511.80 & 507.40 \\
Mean & 21.66 & 21.71 & 21.29 & 497.51 & 506.40 & 505.91 \\
\hline
\end{tabular}


studying the floral development in the tribe Cedraleae: Cedrela and Toona. Flower buds developed on current years shoot growth, whereas few buds are also seen on one year old branches. Nath and Randhawa (1959) reported similar bearing habit in different Pomegranate cultivars.

\subsection{Floral morphology}

Flower buds were found in cymose clusters 3 in number. The buds were elongated and conical in shape. Such type of bearing has also been reported by Dasarthy (1951).Anthesis brings about exposure of anthers and stigma to the pollen vector. Flowers ordinarily open and close at definite hours. In Toona ciliata, the present investigation showed that the flower open between 7 to $1 \mathrm{pm}$ the time of anthesis is effected by the increase and decrease in temperature. Almost similar timings had been observed in different tree species by various workers viz., Srivastava (1983) reported that in Palash anthesis took place between 5 to 6 am Balalia and Chauhan (1994) in Delonix regia recorded maximum flower open in between 6 to 7 a.m. Chauhan et al. (2004) also brought to light that in Dalbergia sissoo maximum anthesis occurs between 11:30 am to $1: 30 \mathrm{pm}$ (Table 4 and 5). The present investigation revealed that the dehiscence of anthers took place in a longitudinal fashion. The maximum anther dehiscence was observed

\begin{tabular}{|c|c|c|}
\hline SI. No. & Floral particulars & Dimension/number \\
\hline \multirow[t]{3}{*}{1.} & Flower & \\
\hline & i) Diameter (mm) & $3.00-4.00$ \\
\hline & ii)Length (mm) & $4.00-6.00$ \\
\hline \multirow[t]{3}{*}{1.1.} & Calyx & \\
\hline & Number & Five \\
\hline & Length (mm) & $1.00-2.00$ \\
\hline \multirow[t]{3}{*}{1.2.} & Corolla & \\
\hline & No. of petals & Five \\
\hline & Length (mm) & $3.00-4.00$ \\
\hline \multirow[t]{5}{*}{1.3.} & Androecium & \\
\hline & No. of stamen & Five \\
\hline & Fil ament length (mm) & $2.50-2.75$ \\
\hline & Anther length (mm) & $0.25-0.50$ \\
\hline & Stamen length (mm) & $2.00-3.00$ \\
\hline \multirow[t]{4}{*}{1.4.} & Gynoecium & \\
\hline & Style length (mm) & $3.00-4.00$ \\
\hline & Ovary length (mm) & $1.00-1.25$ \\
\hline & Pistil length (mm) & $5.00-6.00$ \\
\hline \multirow[t]{3}{*}{2.0.} & Capsule (Fruit) & \\
\hline & Length (mm) & $15.00-20.00$ \\
\hline & Width (mm) & $6-10$ \\
\hline
\end{tabular}

Table 5: Morphological and floral features of Toona ciliata

\begin{tabular}{ll}
\hline Plant part & \multicolumn{1}{c}{ Features } \\
\hline Leaf & Imparipinnate or paripinnate, lanceolate \\
& or ovate-lanceolate, 8-25 leaflets, oppo- \\
& site or alternate, opposite, acuminate, gla- \\
& brous, pubescent, margin entire or wavy \\
& and base oblique
\end{tabular}

Infloroscence Numerous, drooping or sub-erect terminal panicles, small flowers born in cyme bearing axillary or terminal clusters of 3 florets.

Flower Unisexual, pentaisomerous, dull white coloured, imperfect.

Calyx Sepals five, sepals fused at base, green lanceolate with acute tip

Corolla Petals five, ovate-oblong, lanceolate, greenish dull white, acuminate tip, subacute with ciliate margins.

Androecium Stamens five, free, Filaments are white, two anther lobes.

Gynoecium Globose in female, conical in functionally male flowers, five loculiBicarpellary, syncarpous and unilocular ovoid-elliptic ovary having ovules. Stigma capitate borne on short and slender style.

Fruit Egg shaped dark brown form one side bearing numerous seeds.

Seeds

Seeds very light, brown or light brown or dark brown, winged and pyramidal in outline.

between 7:00 am to 8:30 am in the samples from all the three sites. The results are consistent with those of Wani (2005), who observed the similar pattern of anther dehiscence in Bauhinia variegata also reported anther dehiscence timings between 6:30 to 9:30 am Pantet et al. (1997) observed the longitudinal pattern of anther dehiscence in Grewia optiva. The observations are supported by the studies conducted by Srivastava (1983) while working on Butea monosperma (Palash) also found that anther dehisced between 5 to $6 \mathrm{am}$. Sareen and Vashisht (1982) established in Delonix regia that anthers dehisced by longitudinal slits occurring between 10:30 to $11: 30$ am and $3: 30$ to $4 \mathrm{pm}$. Stigma became receptive to the pollen germination 1 day after initiation of anthesis. Stigma receptive period extended to full blossomed flower (Table 6). Similar mode has been observed by Randhawa and Das (1962) in Grewia asiatica where stigma was fully receptive on the day of anthesis. Srivastava et al. (1987) in Moghania chappar and Pant et al. (1997) in Grewia optiva, where the receptivity of stigma range from $24 \mathrm{hrs}$ before anthesis to $12 \mathrm{hrs}$ after anthesis. Chauhan et al. (2004) in Dalbergia sissoo observed that stigma became receptive few hours before anthesis and 
Table 6: Corresponding sequence of events leading to anther and stigma maturation

\begin{tabular}{|c|c|c|}
\hline Floral stage & Stage of anther & Stage of stigma \\
\hline Unopened & $\begin{array}{c}\text { Anthers imma- } \\
\text { ture }\end{array}$ & $\begin{array}{l}\text { Stigma fully } \\
\text { grown }\end{array}$ \\
\hline $\begin{array}{l}\text { Flower begun to } \\
\text { open }\end{array}$ & $\begin{array}{l}\text { Anther matured } \\
\text { and started to } \\
\text { dehisce (pollen } \\
\text { shading) }\end{array}$ & $\begin{array}{c}\text { Capitate } \\
\text { stigmatic lobes } \\
\text { prominent }\end{array}$ \\
\hline Full blooming stage & $\begin{array}{l}\text { Maximum an- } \\
\text { ther dehiscence } \\
\text { (pollen shed- } \\
\text { ding) }\end{array}$ & $\begin{array}{l}\text { Stigma recep- } \\
\text { tive }\end{array}$ \\
\hline $\begin{array}{l}\text { Flower begun to } \\
\text { drying }\end{array}$ & $\begin{array}{l}\text { Anther dehis- } \\
\text { cence almost } \\
\text { completed but } \\
\text { some pollen still } \\
\text { adhering to the } \\
\text { anther surface }\end{array}$ & $\begin{array}{c}\text { Stigmatic lobes } \\
\text { start drying and } \\
\text { loose receptiv- } \\
\text { ity }\end{array}$ \\
\hline $\begin{array}{l}\text { Complete drying of } \\
\text { flowers }\end{array}$ & $\begin{array}{c}\text { Anthers fully } \\
\text { dried }\end{array}$ & $\begin{array}{l}\text { Stigma dried } \\
\text { completely }\end{array}$ \\
\hline
\end{tabular}

remain receptive for few hours after anthesis.

\subsection{Breeding system}

Pollination mechanisms in plants have a decisive bearing upon rational procedure in plant breeding activities. The nature of the assemblage of genotype depends to a high degree on extend of natural recombination of traits, genetic uniformity within a population, degrees of homozygosity all being subjected to the past and prevalent modes of pollination. Isolation or selection procedure must be based on the behaviour of the individual or population of phenotypes. Sexual hybridization finally constitutes controlled pollination, implementation of which obviously depends on pollination, which is extremely important for seed yield where seed set is required. The present findings are supported by the observations of various workers viz., Bryndum and Hedegart (1969) in Teak. Taroda and Gibbs (1982) in controlled pollination experiment of Sterculia chica found that the species is a self incompatible one. Ramirez et al. (1984) in Bauhina ungulate reported genetically self incompatible and functionally andromonoecious. Bawa et al. (1985) found that majority of trees species in the rain forest appear to be an obligate out crossing ones. Pant et al. (1997) observed that Grewia optiva is predominantly a cross pollinated species, Bhattacharya and Mandal (2000) in Bombax ceiba detected no fruit setting in netted and bagged flowers, and reported that some external agents are required for successful pollination. Similar observations have been recorded by Hicks et al. (1985) in Mitchella repens. Pollen morphology was recorded as (3)4-colporate, isopolar, radiosymmetric, small; circular to slightly prolate oval (often \pm depressed or compressed oval, i.e., poles or sides slightly flattened), rarely oblate. Kodela (2000) found the similar pattern of pollen morphology in Synoum glandulosum, Toona ciliata and Legne phoramoorei. The results for pollen size studied from flowers of individual trees were found to show non significant size variation. Also the same results were recorded for site to site variation which suggests that pollen size remains the same irrespective of location and individual tree variability (Table 7). Studies revealed that self pollination facilitated through control pollination led to successful seed setting which suggest that there is no self incompatibility in this species (Table 8). The results on fruit set shown in Table 8 revealed that the seed appeared well after bagging. It could be concluded that Toona ciliata is self compatible and selfing had taken place. The present findings are supported by Dolidez and Joly (1997) who studied Carapa procera population located within a sylvicultural trial in French Guiana and found that a significant fraction of the offspring were produced by selfing. It is also further supported by Bawa (1992) that C. procera is self compatible. Lemes et al. (2007) also found that Swietenia macrophylla seems to have adaptations that preferentially

Table 7: Mean pollen size ( $\mu \mathrm{m})$ of Toona ciliata at different sites

\begin{tabular}{lccc}
\hline Tree No. & Jaunaji $\left(\mathrm{L}_{1}\right)$ & Dharja $\left(\mathrm{L}_{2}\right)$ & Kandaghat $\left(\mathrm{L}_{3}\right)$ \\
\hline $\mathrm{T}_{1}$ & 27.86 & 28.14 & 27.64 \\
$\mathrm{~T}_{2}$ & 27.64 & 27.64 & 28.04 \\
$\mathrm{~T}_{3}$ & 28.14 & 28.04 & 28.18 \\
$\mathrm{~T}_{4}$ & 27.64 & 28.22 & 27.64 \\
$\mathrm{~T}_{5}$ & 28.04 & 27.98 & 27.64 \\
$\mathrm{~T}_{6}$ & 28.22 & 28.18 & 28.04 \\
$\mathrm{~T}_{7}$ & 27.98 & 27.64 & 28.14 \\
$\mathrm{~T}_{8}$ & 28.18 & 28.14 & 28.22 \\
$\mathrm{~T}_{9}$ & 28.04 & 27.64 & 27.64 \\
Mean & 27.97 & 27.96 & 27.91 \\
\hline
\end{tabular}

\begin{tabular}{lccc}
\hline \multicolumn{4}{c}{ Table 8: Mean fruit setting in different seed sources } \\
\hline Tree No. & Jaunaji $\left(\mathrm{L}_{1}\right)$ & Dharja $\left(\mathrm{L}_{2}\right)$ & Kandaghat $\left(\mathrm{L}_{3}\right)$ \\
\hline $\mathrm{T}_{1}$ & 10.8 & 12.0 & 10.2 \\
$\mathrm{~T}_{2}$ & 10.6 & 11.4 & 13.4 \\
$\mathrm{~T}_{3}$ & 10.0 & 10.6 & 11.0 \\
$\mathrm{~T}_{4}$ & 9.8 & 11.0 & 12.8 \\
$\mathrm{~T}_{5}$ & 9.8 & 14.8 & 12.0 \\
$\mathrm{~T}_{6}$ & 11.4 & 10.4 & 11.4 \\
$\mathrm{~T}_{7}$ & 11.0 & 9.2 & 10.6 \\
$\mathrm{~T}_{8}$ & 10.8 & 13.4 & 12.0 \\
$\mathrm{~T}_{9}$ & 2.2 & 15.2 & 12.4 \\
Mean & 9.6 & 12 & 11.76 \\
\hline
\end{tabular}


produce outcrossed progeny but also allow for selfing.

\subsection{Genetic estimates}

Genetic estimates for number of flowers, inflorescence length, fruit setting calculated revealed the heritability values (broad sense) of $0.41,0.62$ and 0.48 respectively. The leaflet size was also found to be under strong genetic control (0.57). Therefore, from Table 9 it can be inferred that these traits were under the strong genetic control supported by Dean and Burdon (1991).

\begin{tabular}{|c|c|c|c|c|c|}
\hline $\begin{array}{l}\text { Character } \\
\text { studied }\end{array}$ & GCV & PCV & $\begin{array}{l}\text { Heritability } \\
\qquad\left(h^{2}\right)\end{array}$ & $\begin{array}{l}\text { Genetic } \\
\text { advance }\end{array}$ & $\begin{array}{l}\text { Genetic } \\
\text { gain (\%) }\end{array}$ \\
\hline $\begin{array}{l}\text { No. of } \\
\text { flower }\end{array}$ & 7.86 & 9.14 & 0.41 & 10.42 & 9.14 \\
\hline $\begin{array}{l}\text { Inflores- } \\
\text { cence } \\
\text { length }\end{array}$ & 11.75 & 11.03 & 0.62 & 19.01 & 11.03 \\
\hline $\begin{array}{l}\text { Leaf let } \\
\text { Size }\end{array}$ & 11.82 & 11.65 & 0.57 & 18.46 & 11.65 \\
\hline $\begin{array}{l}\text { Fruit set- } \\
\text { ting }\end{array}$ & 18.75 & 20.15 & 0.48 & 26.9 & 20.15 \\
\hline $\begin{array}{l}\text { No. of } \\
\text { Leaf let }\end{array}$ & 8.52 & 11.06 & 0.33 & 10.15 & 11.06 \\
\hline
\end{tabular}

GCV: Genotypic coefficient of variability; PCV: Phenotypic coefficient of variability; Correlation studies

\subsection{Correlation studies}

The expression of a character is sum total of the contribution of so many other character and therefore, screening or selection should be done on the basis of components contributing towards that character. The biometrical tool for helping this is correlation which gives the nature and degree of association between various traits. So, the knowledge of association of different characters is the first hand information for any improvement programme (Table 10). Positive and significant correlation among various floral characteristics

Table 10: Simple correlation for different characters of Toona ciliata

\begin{tabular}{lrrrrrr}
\hline & FN & \multicolumn{1}{c}{ IL } & \multicolumn{1}{c}{ LLS } & \multicolumn{1}{l}{ LN } & \multicolumn{1}{l}{ FS } & PS \\
\hline FN & 1 & $0.941^{*}$ & 0.343 & -0.185 & 0.08 & 0.193 \\
IL & & 1 & 0.302 & -0.044 & 0.092 & 0.221 \\
LLS & & & 1 & -0.008 & -0.181 & 0.055 \\
LN & & & & 1 & -0.249 & 0.376 \\
FS & & & & & 1 & -0.099 \\
PS & & & & & & \multicolumn{2}{c}{1} \\
\hline
\end{tabular}

FN: Flower no.; IL: Inflorescence length; LLS: Leaf let size; LN: Leaflet no.; FS: Fruit setting; PS: Pollen size; ${ }^{*}$ : Correlation is significant at the 0.01 level (2-tailed). namely inflorescence length and flower number $(r=0.94)$ was recorded which is supported by the findings of Michael et al. (2002) in Lycopersicon pimpinellifolium that phenotypic correlations among traits such as flowers per inflorescence; petal, anther, and style lengths; and lengths of the fertile and sterile portions of anthers were all positive. The other parameter viz. leaflet number per leaf and fruit setting were found to be least correlated which reflects that the leaflet character is much influenced by vegetative growth and least by the culmination of reproductive growth into fruit formation.

\section{Conclusion}

Toona ciliata may be worked for phenotypic selections, individual tree superiority and inflorescence characteristics through appropriate selection procedures and the reproductive biology also offers a vast potentiality for improvement of the species

\section{References}

Bahadur, K.N., 1988. Monograph on the genus Toona (Meliaceae). Bishen Singh Mahendra Pal. International book Distributors. Dehradun.

Balalia, R., Chauhan, S.V.S., 1994. Phenology and reproductive biology of some leguminous trees. Journal of Tree Sciences 13(2), 121-123.

Bawa, K.S., Perry, D.R., Beach, J.H., 1985. Reproductive biology of tropical lowland rain forest trees. I. Sexual systems and incompatibility mechanisms. American Journal of Botany 72, 331-345.

Bawa, K.S., 1992. Mating systems, genetic differentiation and speciation in tropical rain forest plants. Biotropica 24, 250-255.

Bhattacharya, A., Mandal, S., 2000. Pollination biology of Bombax ceiba Linnean. Current Science 79(12), 1706-1712.

Bryndum, K., Hedegart, T., 1969. Pollination of teak (Tectona grandis Linn. f.). Silvae Genetica 18, 77-80.

Champion, H.G., Seth, S.K., 1968. A revised survey of the forest types of India. Manager of publications.Govt. of India Press, New Delhi, 404.

Chauhan, R., Chauhan, S., Khajuria, H.N., 2004. Reproductive biology and variability studies in Dalbergia sissoo (Roxb.). Advances in Forestry Research in India 28, 24-37.

Chowdhury, R., Hasan, C.M., Rashid, M.A., 2003. Antimicrobial activity of Toona ciliata and Amoora rohituka. Fitoterapia 74(1-2), 155-158.

Dasarathy, T.B., 1951. Effect of pruning on growth and fruiting of guava. Madras Agriculture Journal 38, 520-526.

Dean, C.A., Burdon, R.D., 1991. Early selection of Radiata pine. I. Trends over lining additive and dominancegenetic variances and co-variances for growth traits. Silvae Genetics 40, 37-40.

Doligez Agne, S., Joly, H.L.N.I., 1997. Mating system Of Carapa 
Procera (Meliaceae) in the French Guiana Tropical Forest. American Journal of Botany 84(4), 461-470.

Gopalakrishnan, G., Singh, N.D.P., Kasinath, V., Malathi, R., Rajan, S.S., 2000. Photo oxidation of cedrelone, a tetranortriterpenoid from Toona ciliata. Photochem Photobiol 72, 464-466.

Gouvea, C.F., Dornelas, M.C., Rodriguez, A.P.M., 2008. Floral development in the tribe Cedreleae (Meliaceae, subfamily Swietenioideae): Cedrela and Toona. Annals of Botany 101(1), 39-48.

Heinrich, I., Banks, J.C.G., 2006. Variation in phenology, growth, and wood anatomy of Toona sinensis and Toona ciliata in relation to different environmental conditions. International Journal of Plant Sciences 167(4), 831-841.

Hicks, D.J., Wyatt, R., Meagher, T.R., 1985. Reproductive Biology of Distylous Partridgeberry, Mitchellarepens. American Journal of Botany 72(10), 1503-1514.

Kodela, P.G., 2000. Pollen morphology of some rainforest taxa occurring in the Illawarra region of New South Wales, Australia. Telopea 11(3), 346-389.

Lemes, M.R., Grattapaglia, D., Grogan, J., Proctor, J., Gribel, R., 2007. Flexible mating system in a logged population of Swietenia macrophylla King (Meliaceae): Implications for the management of a threatened Neotropical tree species. Plant Ecology 192, 169-179.

Malairajan, P., Gopalakrishnan, G., Narasimhan, S., Jessi, K.V.K., 2006. Analgesic activity of some Indian medicinal plants. J Ethnopharmacol 106, 425-428.

Michael, S., Richard, G., Whitkus, W., Lord, E.M., 2002. Genetic analysis of traits distinguishing outcrossing and self-pollinating forms of currant tomato, Lycopersicon pimpinellifolium (Jusl.) Mill. Genetics 161, 333-344.

Negi, S.J., Bisht, V.K., Bhandari, K.A., Bharti, M.K., Sundriyal, R.C., 2011. Chemical and pharmacological aspects of Toona(Meliaceae). Res J Phytochem 5, 14-21.
Nath, N., Randhawa, G.S., 1959. Studies on floral biology in the pomegranate (Punica granatum L.). Indian Journal of Horticulture 16, 121-135.

Pant, K.S., Sehgal, R.N., Sharma, S.S., 1997. Floral biology and breeding system in Grewia optiva Drummond. Indian Journal of Forestry 20(4), 309-313.

Ramirez, N., Sobrevila, C., Enrcch, N., Ruiz Zapaia, T., 1984. Floral biology and breeding system of Bauhinia benthamianaTaub. (Leguminosae). A Bat Pollinated Tree in Venezuelan "LLANOS". American Journal of Botany 71(2), 273-280.

Randhawa, G.S., Dass, H.C., 1962. Studies on floral biology of phalsa (Grewia asiatica Linn). Indian Journal of Horticulture 19(1), 8-24.

Sareen, T.S., Vasisht, S., 1982. Breeding systems of Delonix regia Raf. (Syn. Poinciana regia Bojer). In: Khosla, C.D. (Ed.), Improvement of Forest Biomass. P.KL Pragati Press, Delhi, 33-40.

Shaohong, C., Pengkang, R., Yuntao, Z., 2010. Inhibitory effects of ethanol extract from Toona sinensis leaves on the formation of protein non-enzymatic. Journal of Anhui Agricultural Sciences 11, 5642.

Singh, R.V., 1982. Fodder trees of India. Oxford and IBH Publishing Company, New Delhi, India 663.

Srivastava, S.C., 1983. Floral biology of palas: Butea monosperma (LAM.) Taub. Indian Journal of Forestry $6(8), 57-62$.

Taroda, N., Gibbs, P.E., 1982. Floral biology and breeding system of Sterculia Chichast.hil. (sterculiaceae). New Phytologist 90, 735-743.

Wani, A.M., 2005. Reproductive biology and genetic variability in Bauhinia variegata LINN. Phd. Thesis, Dr. Y. S. Parmar University of Horticulture and Forestry, Solan, India, 104.

Weberling, 1989. Morphology of flowers and inflorescences, Cambridge University Press, New York, 496. 